Images in...

\title{
Aneurysm of a coronary vein graft
}

\author{
Mark Ainslie, Nicholas Brooks \\ Department of Cardiology, Wythenshawe Hospital, Manchester, UK \\ Correspondence to Mark Ainslie, markpeterainslie@hotmail.com
}

\section{DESCRIPTION}

A 75-year-old man with coronary bypass grafts presented with an episode of chest pain, transient lateral ST depression and $12-\mathrm{h}$ troponin of $1 \mathrm{pg} / \mathrm{ml}$. Angiography revealed severe native vessel disease, a patent internal mammary graft to the anterior descending, occlusion of a vein graft to the circumflex and an aneurysm in a vein graft to the right coronary artery. This was approximately $2.5 \mathrm{~cm}$ in diameter when measured (figure 1).

His presentation was ascribed to either circumflex graft occlusion or embolisation from the right coronary graft.

A CT scan showed the ectatic graft with a fusiform aneurysm over $6 \mathrm{~cm}$ in length and with a diameter of 5.7 $\times 4.8 \mathrm{~cm}$. Extensive mural thrombus resulted in a residual lumen of $2.6 \mathrm{~cm}$ (figure 2).

This meant that angiography greatly underestimated its size.

He remained asymptomatic and was managed conservatively after a multidisciplinary discussion with the surgeons.

Mild aneurysmal dilation of coronary vein grafts is common, with a frequency of approximately $14 \%$ within $5-7$ years of surgery. Large aneurysms, greater than $2 \mathrm{~cm}$, are rare. ${ }^{1}$

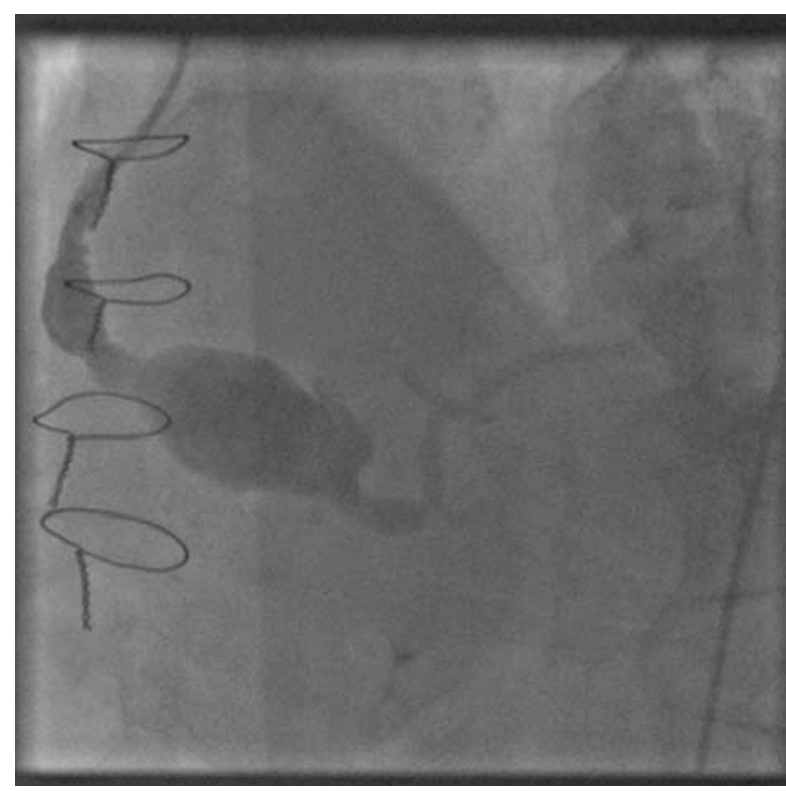

Figure 1 Angiography. Saphenous vein graft aneurysm noted to right coronary artery.
Aneurysms are often asymptomatic and detected incidentally on chest radiography, but may present with an acute coronary syndrome, heart failure, acute rupture or from local pressure complications. ${ }^{2}$

Management strategies include ligation, coil embolisation and implantation of a covered stent.

Angiography can clearly demonstrate them but will not show organised thrombus in the wall, thus if detected patients should undergo further imaging in the form of contrast CT or MRI.

Surveillance imaging is recommended in those conservatively managed.

Competing interests None.

Patient consent Obtained.

\section{REFERENCES}

1. Nishimura K, Nakamura Y, Harada S, et al. Saphenous vein graft aneurysm after coronary artery bypass grafting. Ann Thorac Cardiovasc Surg 2009;15:61-3.

2. Kalimi R, Palazzo RS, Graver LM. Giant aneurysm of saphenous vein graft to coronary artery compressing the right atrium. Ann Thorac Surg 1999:68:1433-7.

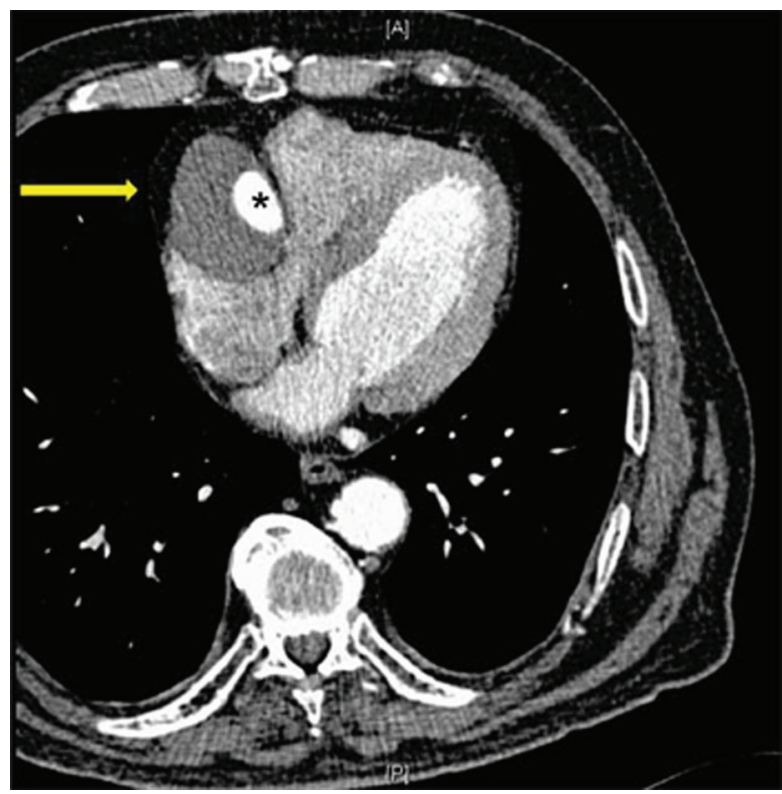

Figure 2 CT chest. Arrow shows aneurysm with large eccentric thrombus and small lumen (asterisk). 


\section{BMJ Case Reports}

This pdf has been created automatically from the final edited text and images.

Copyright 2011 BMJ Publishing Group. All rights reserved. For permission to reuse any of this content visit http://group.bmj.com/group/rights-licensing/permissions.

BMJ Case Report Fellows may re-use this article for personal use and teaching without any further permission.

Please cite this article as follows (you will need to access the article online to obtain the date of publication).

Ainslie M, Brooks N. Aneurysm of a coronary vein graft. BMJ Case Reports 2011;10.1136/bcr.12.2010.3605, date of publication

Become a Fellow of BMJ Case Reports today and you can:

- Submit as many cases as you like

- Enjoy fast sympathetic peer review and rapid publication of accepted articles

- Access all the published articles

- Re-use any of the published material for personal use and teaching without further permission

For information on Institutional Fellowships contact consortiasales@bmjgroup.com

Visit casereports.bmj.com for more articles like this and to become a Fellow 